\title{
PENINGKATAN KREATIVITAS MAHASISWA DALAM PEMBELAJARAN IPA DENGAN MODEL PROBLEM BASED LEARNING DI JURUSAN PGSD FIP UNP
}

\author{
Nelly Astimar, Firman \\ Jurusan Pendidikan Guru Sekolah Dasar Fakultas Ilmu Pendidikan \\ Universitas Negeri Padang
}

\begin{abstract}
Students difficulties in determining and analyzing issues relating to science learning, especially the human reproductive material as well as the adaptation and evolution of living beings. In addition, students' ability to think creatively to solve problems relating to science teaching is still low, especially human reproductive material as well as the adaptation and evolution of living beings. Therefore, one way to improve it is by the use of Problem Based Learning in learning science is assumed to be able to develop the creative abilities of students. This study aimed to describe the increase in the creativity of students in science learning Problem Based Learning model in the Department PGSD FIP UNP. This kind of research is classroom action research using qualitative and quantitative approaches. Subjects in this study were students R08 section in the student section III UPP $R$ 08. The research was conducted in three cycles, with each cycle consisting of planning, implementation, observation and reflection. Data of this study was the observation of any action on the learning process by using the observation sheet. The results showed improvement in terms of: (a) the first cycle RPP $68.75 \%$ to $83.33 \%$ in the second cycle and $95.83 \%$ in the third cycle, (b) the observation that the implementation of the activity seen in the first cycle lecturer 73.22 $\%$ to $89.29 \%$ in the second cycle and $96.43 \%$ in the third cycle, activities of students in the first cycle of $62.5 \%$ to $82.14 \%$ in the second cycle and $94.65 \%$ in the third cycle, (c) an increase in student creativity involved in each cycle in the human reproductive material is of $41 \%$ in the first cycle, 59\% in the second cycle and $100 \%$ in the third cycle. Besides, also, the acquisition of the average percentage of the value of creative thinking of students also increased to be good and very good. Based on the material: adaptation and evolution, there is an increase in the creativity of students involved in each cycle is of $22 \%$ in the first cycle, $67 \%$ in the second cycle and $100 \%$ in the third cycle. Besides, also, the acquisition of the average percentage of the value of creative thinking of students also increased from less, enough to be good and very good.
\end{abstract}

Keywords : creativity of students, learning science, Problem Based Learning

PENDAHULUAN

Pembelajaran IPA merupakan pembelajaran wajib di jurusan PGSD, dimana setiap mahasiswa harus menguasainya. Konsep dasar IPA menjadi salah satu pelajaran yang akan diajarkan pada siswa SD. Selama ini, materi pembelajaran IPA masih banyak bersifat abstrak sehingga peserta didik menjadi kurang memahaminya, terutama materi Reproduksi Manusia serta Evolusi dan Adaptasi. Materi tersebut biasanya diberikan dengan metode pembelajaran konvensional yaitu berupa ceramah, diskusi dan tanya jawab. Metode itu ternyata belum memaksimalkan kreativitas berpikir mahasiswa, sehingga mahasiswa tidak semangat untuk mengikuti materi kuliah. 
Pada akhirnya setelah mahasiswa tersebut menjadi guru, banyak yang mengalami kesulitan dalam memberikan materi kepada siswa.

Selain strategi pembelajaran yang belum tepat, pembelajaran materi reproduksi manusia dan evolusi serta adaptasi makhluk hidup di dalam silabus yang diajarkan masing-masing pokok materi ajar 2 x 50 menit. Dengan waktu yang demikian singkat, belum banyak informasi yang bisa digali secara mendalam. Akibatnya materi yang diberikan dalam pembelajaran IPA di SD dalam pemberian contoh-contoh yang ada dalam kehidupan sehari-hari terlalu minim, sehingga banyak mengalami kesulitan terutama dalam aplikasi untuk kehidupannya. Dengan demikian, materi ini perlu diangkatkan peneliti sebagai bahan kajian.

Belum munculnya kreativitas berpikir mahasiswa untuk dapat mencari contohcontoh dari yang dekat di lingkungan mereka tentang reproduksi manusia serta adaptasi dan evolusi. Banyak masalah atau topik yang diberikan kepada mahasiswa untuk dapat diaplikasikan dalam kehidupan nyata belum dapat diselesaikan dengan baik.

Peneliti mencoba untuk mengatasi masalah di atas dengan menggunakan strategi problem based learning dan sistem informatika yang telah berkembang di tengah-tengah masyarakat. Problem based learning itu merupakan strategi pembelajaran berbasis masalah yang dapat meningkatkan proses berpikir kreatif mahasiswa. Sebagaimana yang dikemukakan oleh Tan, et al (dalam Rusman, 242) bahwa "1) hambatan siswa dalam kemampuan berpikir dan memecahkan masalah; 2) belajar berbagai peran orang dewasa melalui pelibatan mereka dalam pengalaman nyata; 3) menjadi para siswa yang otonom".
Mahasiswa dapat dikatakan kreatif apabila telah menghasilkan suatu produk dari pemikiran kreatif berupa hal baru atau inovasi dari produk lama yang diperbaharui. Munandar $(2004 ; 19)$ menjelaskan bahwa: "Kreativitas adalah suatu gaya hidup, suatu cara dalam memersepsikan dunia". Hidup kreatif berarti mengembangkan talenta yang dimiliki, belajar menggunakan kemampuan sendiri secara optimal, menjajaki gagasan baru, tempat-tempat baru, aktivitas-aktivitas baru; mengembangkan kepekaan terhadap masalah lingkungan, masalah orang lain dan masalah kemanusiaan.

Berdasarkan permasalahan di atas, peneliti berusaha untuk mencari solusi bagi mahasiswa PGSD agar kreativitasnya lebih meningkat dibandingkan dengan Diploma (DII). Selama ini penekanan terhadap materi IPA belum diiringi dengan pengalaman IPA dalam kehidupan sehari-hari sehingga berpikir kreatif kurang terlihat. Salah satu cara peningkatan kreativitas mahasiswa adalah dengan metode pengajarannya. Metode pengajaran merupakan salah satu sebab tidak munculnya kreativitas berpikir mahasiswa.

Berdasarkan permasalah tersebut, penulis menganggap bahwa pendekatan Problem Based Learning (PBL) sesuai digunakan untuk mengatasi permasalahan yang telah dijabarkan sebelumnya. PBL merupakan sebuah strategi yang berasal dari permasalahan yang berkaitan erat dengan dunia nyata. Amir (2010:22) mengungkapkan bahwa "semakin dekat masalah yang disajikan dengan dunia nyata, akan semakin baik pengaruhnya pada peningkatan kemampuan pemelajar". Dengan kata lain, pembelajaran yang bersifat nyata nantinya akan lebih mudah dipahami oleh mahasiswa dan tujuan dari pembelajaran tersebut akan tercapai. 
Tujuan dari penelitian ini adalah untuk mendeskripsikan "peningkatan kreativitas mahasiswa dalam pembelajaran IPA dengan model Problem Based Learning di Jurusan PGSD FIP UNP".

Kreativitas itu sendiri menurut pengertian sederhana yang dikemukakan oleh Deswita (2006;174), "kreativitas adalah kemampuan untuk menciptakan sesuatu yang baru melalui proses berpikir kreatif yang berlangsung dalam pikiran orang atau sekelompok orang, produk-produk kreatif tercipta". Dalam semua bentuk tersebut selalu ada sifat dasar yang sama, yaitu keberadaan yang baru atau belum pernah ada sebelumnya. Sifat baru itulah yang menandai produk proses atau seseorang kreatif.

Guilford (dalam Munandar, 2004) bahwa; orang-orang kreatif lebih banyak memiliki cara-cara berpikir divergen daripada konvergen. Lebih lanjut Guilford mengemukakan dua ciri berpikir yaitu; cara berpikir konvergen dan divergen. Cara berpikir konvergen adalah cara-cara individu dalam memikirkan sesuatu dengan berpandangan bahwa hanya ada satu jawaban yang benar. Sedangkan cara berpikir divergen adalah kemampuan individu untuk mencari berbagai alternatif jawaban terhadap suatu persoalan dalam kreativitas. Selain itu Guilford (dalam Munandar 1999) juga menerangkan bahwa; "kreativitas merupakan kemampuan atau kecakapan yang ada dalam diri seseorang. Hal ini erat kaitannya dengan bakat, maka mahasiswa perlu memahami kreativitas berpikir yang ada dengan bersikap luwes dan kreatif'.

Teknik kreatif yang akan peneliti gunakan sesuai dengan teknik kreatif menurut Treffinger dimana terbagi atas : 1) tekni kreatif basic tool dimana teknik ini untuk dapat mengembangkan aspek kelancaran, kelenturan, mengungkapkan pemikiran kreatif pada orang lain, orisinil dan elaborasi. Langkah-langkah untuk pelaksanaan :

Banyak contoh memecahkan masalah lain yang memerlukan daya berpikir yang kritis. Meskipun sederhana, menarik kesimpulan dari serangkai percobaan juga merupakan latihan berpikir kritis. Pembelajaran IPA terutama reproduksi manusia serta adaptasi dan evolusi diajarkan melalui pengamatan yang dilakukan sendiri oleh mahasiswa (dengan bantuan pengajar), maka IPA tidaklah merupakan suatu mata kuliah yang bersifat hafalan belaka. Mata kuliah IPA modern lebih mementingkan kemampuan berpikir kritis dari pada kemampuan menghafal dengan teknologinya yang canggih. Disamping itu, dibutuhkan juga kemampuan dalam melakukan pengamatan secara teliti, menggunakan prinsip, memecahkan percobaan sederhana, menyusun data, mengemukakan hipotesanya.

Langkah-langkah problem based learning yang digunakan didasarkan pada pemecahan masalah secara kreatif oleh Parnes. Proses yang dikembangkan Parnes (dalam Munandar, 2004) tersebut yaitu : menemukan fakta, menemukan masalah, menemukan gagasan, menemukan solusi, dan menemukan penerimaan. Tahap pertama didahului dengan ungkapan pikiran dan perasaan mengenai masalah yang dirasakan sebagai gangguan tetapi masih samarsamar. Tahap menemukan fakta ialah tahap mendaftarkan semua fakta yang diketahui mengenai masalah yang ingin dipecahkan dan menemukan data baru yang diperlukan. Tahap ini didahului oleh keadaan "kacau" dan masalahnya masih samar-samar.

Pada tahap menemukan masalah, diupayakan merumuskan masalah dengan memberikan banyak gagasan. Pemikiran diharapkan dapat 
mengembangkan masalahnya dengan menemukenali sub-masalah; masalah dapat dirumuskan kembali atau disempitkan. Pada tahap menemukan gagasan diupayakan mengembangkan gagasan pemecah masalah sebanyak mungkin. Pada tahap penemuan solusi, gagasan yang dihasilkan pada tahap sebelumnya diseleksi berdasarkan kriteria evaluasi yang bersangkut-paut dengan masalahnya, misalnya waktu, biaya, dan tenaga yang diperlukan untuk melaksanakan gagasan tersebut. Pada tahap terakhir, menemukan penerimaan atau tahap pelaksanaan disusun rencana tindakan agar mereka yang mengambil keputusan (pimpinan, orang tua, dan sebagainya) dapat menerima gagasan tersebut dan melaksanakannya.

\section{METODE PENELITIAN}

Jenis penelitian ini merupakan Penelitian Tindakan Kelas (PTK). Penelitian tindakan kelas, yaitu suatu penelitian yang bersifat kolaboratif berdasarkan permasalahan yang muncul dalam kegiatan pembelajaran. Prosedur dan langkah-langkah penelitian ini mengikuti prinsip-prinsip dasar yang berlaku dalam penelitian tindakan. Desain penelitian tindakan terdiri dari empat komponen merupakan siklus mulai dari tahap perencanaan, pelaksanaan tindakan, observasi dan refleksi yang diikuti dengan perencanaan ulang (Suharsimi, 2008:58).

Tahap-tahap penelitian tindakan yang melibatkan secara aktif mahasiswa dan peneliti sebagai kolaborator ini adalah :

1) Pada tahap persiapan kegiatan yang dilakukan adalah : (1) dialog awal untuk mengidentifikasi masalah, dan (2) merumuskan permasalahan untuk perbaikan pembelajaran.
2) Tahap perencanaan yang meliputi: (1) menetapkan alternatif upaya peningkatan kualitas pembelajaran, (2) penentuan metode pembelajaran, (3) penyusunan rancangan tindakan.

3) Pelaksanaan tindakan. Peneliti sebagai kolaborator menerapkan desain pembelajaran Problem Based Learning berbantuan modul.

4) Observasi dan Monitoring, tahap ini dilakukan dalam upaya perbaikan proses pembelajaran dan perencanaan tindakan yang lebih efektif. Peneliti sebagai kolaborator melaksanakan pengamatan secara sistematis terhadap kegiatan mahasiswa.

5) Refleksi berguna sebagai upaya memantapkan kegiatan atau tindakan untuk mengatasi permasalahan dengan memodifikasi perencanaan sebelumnya sesuai dengan apa yang timbul di lapangan.

6) Evaluasi dan revisi dilakukan untuk mengetahui berhasil tidaknya tindakan yang telah dilakukan. Dalam penelitian ini evaluasi meliputi evaluasi jangka pendek dan evaluasi prestasi belajar mahasiswa. Kriteria keberhasilan tindakan dilihat dari: (1) meningkatnya tingkat aktivitas mahasiswa dalam PBM, (2) meningkatnya tingkat kemandirian mahasiswa dalam proses pembelajaran, dan (3) meningkatnya kreativitas mahasiswa,

7) Kesimpulan hasil. Pada tahap ini dibuat pelaporan hasil secara keseluruhan. 
ALUR PENELITIAN TINDAKAN KELAS

Studi Pendahuluan Kreativitas Mahasiswa dengan Model Problem Based Learning

\begin{tabular}{|c|l|l|l}
\hline \multicolumn{1}{|c|}{ Studi Pendahuluan Kreativitas Mahasiswa dengan Model Problem Based Learning } \\
\hline Siklus I \\
Tindakan dan \\
Pengamatan I \\
\hline 1.
\end{tabular}
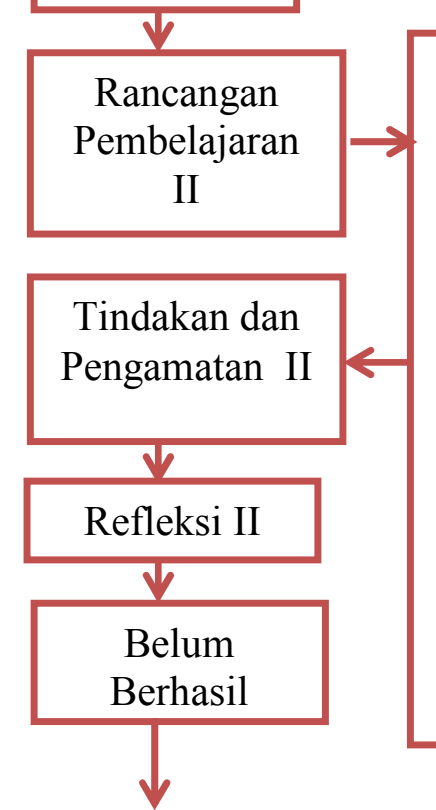

Siklus III

Tindakan dan

Pengamatan

III



1. Orientasi peserta didik pada masalah

Tingkat I (Fungsi Divergen) : (1) Kelancaran dalam mengungkapkan ide-ide; (2) Kelenturan dalam berpendapat

2. Mengorganisasikan peserta didik untuk belajar

3. Membimbing penyelidikan individual maupun kelompok

Tingkat I (Fungsi Divergen) : (3) Orisinilitas; menerapkan pendapat yang asli berasal dari individu

Tingkat III (Keterlibatan dalam Fenomena Nyata) : (1) Pengajuan pertanyaan secara mandiri

4. Mengembangkan dan menyajikan hasil karya

Tingkat I (Fungsi Divergen) : (4) Elaborasi ; gagasan atau ide-ide dapat dijelaskan secara detail

Tingkat II (Proses Berpikir) : (1) Analisis proses berpikir; (5) Keterampilan metodologis untuk memecahkan masalah; (7) Metafor dan analogi terhadap proses berfikir sehingga dapat mengubah gagasan dan mengemukakan ide-ide baru

Tingkat III (Keterlibatan dalam Fenomena Nyata) : (4) Pengembangan produk dan hasil gagasan atau ide-ide kreatif

5. Menganalisis dan mengevaluasi proses pemecahan masalah

Tingkat I (Fungsi Divergen) : (5) Kemampuan menilai.

Tingkat II (Proses Berpikir) : (2) Penerapan kemampuan proses berfikir; (3) Sintesis proses berfikir hasil analisa cepat, tepat; (4) Evaluasi terhadap proses berfikir terhadap masalah yang ditemukan; (6) Transformasi proses berfikir dapat memenuhi kriteria pemecahan masalah

Tingkat III (Keterlibatan dalam Fenomena Nyata) : (2) Pengarahan diri terhadap tantangan-tantangan nyata dalam kehidupan; (3) Pengelolaan dan sumber informasi, tenaga dan biaya

\section{Rencana III \\ Rancangan Pembelajaran III}

1. Orientasi peserta didik pada masalah

Tingkat I (Fungsi Divergen) : (1) Kelancaran dalam mengungkapkan ide-ide; (2) Kelenturan dalam berpendapat

2. Mengorganisasikan peserta didik untuk belajar

3. Membimbing penyelidikan individual maupun kelompok

Tingkat I (Fungsi Divergen) : (3) Orisinilitas; menerapkan pendapat yang asli berasal dari individu

Tingkat III (Keterlibatan dalam Fenomena Nyata) : (1) Pengajuan pertanyaan secara mandiri

4. Mengembangkan dan menyajikan hasil karya

Tingkat I (Fungsi Divergen) : (4) Elaborasi ; gagasan atau ide-ide dapat dijelaskan secara detail

Tingkat II (Proses Berpikir) : (1) Analisis proses berpikir; (5) Keterampilan metodologis untuk memecahkan masalah; (7) Metafor dan analogi terhadap proses berfikir sehingga dapat mengubah gagasan dan mengemukakan ide-ide baru

Tingkat III (Keterlibatan dalam Fenomena Nyata) : (4) Pengembangan produk dan hasil gagasan atau ide-ide kreatif

5. Menganalisis dan mengevaluasi proses pemecahan masalah

Tingkat I (Fungsi Divergen) : (5) Kemampuan menilai.

Tingkat II (Proses Berpikir) : (2) Penerapan kemampuan proses berfikir; (3) Sintesis proses berfikir hasil analisa cepat, tepat; (4) Evaluasi terhadap proses berfikir terhadap masalah yang ditemukan; (6) Transformasi proses berfikir dapat memenuhi kriteria pemecahan masalah

Tingkat III (Keterlibatan dalam Fenomena Nyata) : (2) Pengarahan diri terhadap tantangan-tantangan nyata dalam kehidupan; (3) Pengelolaan dan sumber informasi, tenaga dan biaya 


\section{HASIL PENELITIAN}

\section{Siklus I Pertemuan 1}

Pada tahap perencanaan, peneliti mempersiapkan perangkat pembelajaran IPA berupa RPP dengan penerapan model problem based learning. Adapun komponen penyusunannya dirancang berdasarkan analisis SK dan KD yang dikembangkan menjadi indikator dan kemudian tujuan pembelajaran. Perencanaan pembelajaran disajikan dalam waktu 2 x 50 menit.

Materi yang diambil adalah reproduksi manusia. Adapun kompetensi dasar pada materi reproduksi manusia yaitu mendeskripsikan reproduksi pada manusia. Indikator yang akan dicapai dalam pembelajaran reproduksi manusia pada siklus I adalah : 1) Mahasiswa dapat menjelaskan bagian alat reproduksi manusia, 2) Mahasiswa dapat menjelaskan proses terbentuknya individu baru, 3) Mahasiswa dapat menjelaskan faktor-faktor pendorong dan penghambat terbentuknya individu baru. Untuk mencapai indikator yang telah ditentukan maka peneliti menggunakan strategi Problem Based Learning dalam pembelajaran dengan mengikuti langkah-langkah pembelajaran yang telah ditentukan.

Pelaksanaan pembelajaran dilakukan dengan tiga tahap yaitu kegiatan awal, kegiatan inti dan kegiatan akhir. Pelaksanaannya berdasarkan langkahlangkah dari Problem Based Learning menurut Trianto dalam Taufik (2009 : 372373) yaitu (1) Orientasi peserta didik pada masalah; (2) mengorganisasikan peserta didik untuk belajar; (3) membimbing penyelidikan individual maupun kelompok; (4) mengembangkan dan menyajikan hasil karya; (5) menganalisis dan mengevaluasi proses pemecahan masalah.

1) Hasil Penilaian Rencana Pelaksanaan Pembelajaran (RPP)

Pada dalam siklus 1 instrumen penilaian RPP dilakukan oleh observer. Dari hasil penilaian RPP diperoleh persentase $66,67 \%$ dengan kualifikasi cukup (C).
2) Pengamatan dalam Pelaksanaan Pembelajaran IPA dengan menggunakan model PBL

\section{a) Pengamatan Aspek Dosen}

Hasil pengamatan yang dilakukan observer terhadap aktivitas dosen selaku peneliti dalam kegiatan pembelajaran pada siklus I dalam pembelajaran IPA menggunakan model PBL adalah memperoleh tingkat keberhasilan $71,43 \%$ dengan kategori cukup.

\section{(b) Pengamatan Aktivitas Mahasiswa}

Berdasarkan hasil pengamatan yang dilakukan oleh pengamat terhadap aktivitas mahasiswa dalam kegiatan pembelajaran siklus I, persentase rata-rata aktivitas mahasiswa adalah 57,14\% dengan kategori kurang.

\section{(c) Pengamatan Kreativitas Mahasiswa}

Dari hasil pengamatan terhadap pembelajaran pada siklus I, diperoleh bahwa materi pembelajaran tersebut bagi mahasiswa masih banyak yang belum jelas. Hanya $41 \%$ mahasiswa (11 orang mahasiswa dari 27 mahasiswa) yang berpikir kreatif karena materi pembelajaran masih bersifat abstrak, sehingga pola pikir yang terbentuk dalam proses dan memiliki banyak keragu-raguan. Dari 11 orang tersebut, secara umum memiliki kriteria kurang dengan persentase $61 \%$.

\section{1) Refleksi RPP}

Berdasarkan dari hasil pengamatan yang dilaksanakan, maka untuk selanjutnya dosen perlu memperhatikan hal-hal sebagai berikut: (1) pemilihan materi ajar lebih disesuai dengan lingkungan yang tersedia, (2) materi ajar lebih disesuai dengan bahan yang akan diajarkan, (3) cakupan materi diperluas, (4) pengorganisasian materi yang diajarkan dosen menyesuaikan alokasi waktu yang ditentukan, (5) pemilihan sumber dan media pembelajaran lebih dekat dan sesuai dengan karakteristik mahasiswa, (6) pemilihan sumber dan media pembelajaran lebih dekat dan sesuai dengan lingkungan mahasiswa, (7) langkah pembelajaran 
sesuai dengan alokasi waktu, (8) teknik pembelajaran sesuai dengan lingkungan mahasiswa.

\section{2) Refleksi Pelaksanaan Pembelajaran IPA dengan Menerapkan Model PBL}

\section{(a) Refleksi Aspek Dosen}

Berdasarkan dari hasil pengamatan, maka untuk selanjutnya dosen perlu memperhatikan hal-hal berikut: (1) dalam orientasi mahasiswa kepada masalah, dosen lebih menyempurnakan jawaban mahasiswa. (2) Dalam mengorganisasikan mahasiswa untuk belajar, dosen perlu menjelaskan poin-poin yang akan dibahas secara berkelompok. (3) Dalam membimbing penyelidikan individual maupun kelompok, dosen menyediakan alat dan bahan pembelajaran sehingga mahasiswa bisa memperoleh informasi dari berbagai sumber lainnya.

(4) Dalam mengembangkan dan menyajikan hasil karya, dosen meminta semua kelompok tampil untuk mempresentasikan laporannya dan memotivasi mahasiswa untuk bertanya atau memberikan saran, (5) Dalam menganalisis dan mengevaluasi proses pemecahan masalah, dosen meminta mahasiswa lain untuk menilai hasil presentasi laporan dari kelompok penyaji dan meminta kelompok penyaji untuk menjawab semua pertanyaan mahasiswa lain. (6) Pada kegiatan akhir, dosen perlu memberikan penguatan terhadap hasil diskusi.

\section{3) Refleksi Aspek Mahasiswa}

Berdasarkan hasil pengamatan, maka untuk selanjutnya dosen perlu memperhatikan: (1) Dalam mengkondisikan kelas dan apppersepsi, dosen mengarahkan mahasiswa untuk bersikap tenang. (2) Dalam orientasi mahasiswa kepada masalah, dosen memotivasi mahasiswa untuk menjawab pertanyaan yang diberikan dosen tentang reproduksi manusia, dan mahasiswa mengungkapkan masalah tentang objek yang pernah diamati sebelumnya terkait permasalahan tersebut. (3) Dalam mengorganisasikan mahasiswa untuk belajar, dosen perlu mengarahkan tugas yang akan dikerjakan mahasiswa dan peranan masing-masing anggota kelompok dalam mengerjakan tugas tersebut.

(4) Dalam membimbing penyelidikan individual maupun kelompok, dosen perlu menyiapkan alat dan bahan untuk pembelajaran sehingga mahasiswa dapat memperoleh informasi dari sumber lainnya, dan dosen perlu memotivasi mahasiswa dalam menyampaikan ide dan pendapatnya dalam melakukan diskusi kelompok. (5) Dalam mengembangkan dan menyajikan hasil karya, dosen perlu mengefektifkan waktu agar mahasiswa tampil dapat tampil untuk mempresentasikan laporannya dalam waktu yang singkat, dan memancing mahasiswa lain untuk bertanya atau memberikan saran. (6) Dalam menganalisis dan mengevaluasi proses pemecahan masalah, dosen perlu mengarahkan mahasiswa untuk menilai hasil presentasi laporan dari kelompok penyaji dan mengarahkan kelompok penyaji untuk menjawab pertanyaan dari mahasiswa lain. (7) Dalam menyimpulkan, dosen memancing mahasiswa untuk merespon pernyataan dosen.

\section{4) Refleksi Kreativitas Mahasiswa}

Berdasarkan hasil penilaian kreativitas mahasiswa, maka dapat dilihat deskriptor yang belum tercapai dalam kreativitas yang diuraikan sebagai berikut: Pada siklus I di tingkat I (fungsi divergen) belum tercapai karena mahasiswa belum lentur dalam berpendapat; pendapat belum orisinil; elaborasi belum tercapai dan kemampuan menilai belum sempurna. Untuk selanjutnnya perlu memperbaiki kegiatan yang dilakukan untuk orientasi peserta didik, dan perlu memaksimalkan kegiatan dalam membimbing penyelidikan individual maupun kelompok, mengembangkan dan menyajikan hasil karya serta menganalisis dan mengevaluasi proses pemecahan masalah.

Indikator yang belum tercapai pada tingkat II (proses berpikir) karena mahasiswa 
belum menganalisis proses berfikir; menerapkan kemampuan proses berfikir; melakukan sintesis proses berfikir hasil analisa cepat dan tepat; melakukan evaluasi terhadap proses berfikir terhadap masalah yang ditemukan; keterampilan metodologis untuk memecahkan masalah; transformasi proses berfikir dapat memenuhi kriteria pemecahan masalah; (metafor dan analogi terhadap proses berfikir sehingga dapat mengubah gagasan dan mengemukakan ideide baru. Untuk itu perlu dilakukan memaksimalkan langkah pembelajaran yaitu mengembangkan dan menyajikan hasil karya; serta menganalisis dan mengevaluasi proses pemecahan masalah.

Pada tingkat III (keterlibatan dalam fenomena nyata) belum tercapai karena mahasiswa belum maksimal dalam pengajuan pertanyaan secara mandiri; pengarahan diri terhadap tantangantantangan nyata dalam kehidupan; pengelolaan dan sumber informasi, tenaga dan biaya; dan pengembangan produk dan hasil gagasan atau ide-ide kreatif. Untuk selanjutnya perlu memaksimalkan langkah pembelajaran yaitu: membimbing penyelidikan individu maupun kelompok, mengembangkan dan menyajikan hasil karya; serta menganalisis dan mengevaluasi proses pemecahan masalah. Dan dengan pertanyaan yang mengarahkan mahasiswa dalam menemukan jawabannya.

\section{Siklus I Pertemuan 2}

Pada tahap perencanaan, peneliti mempersiapkan perangkat pembelajaran IPA berupa RPP dengan penerapan model problem based learning. Adapun komponen penyusunannya dirancang berdasarkan analisis SK dan KD yang dikembangkan menjadi indikator dan kemudian tujuan pembelajaran. Perencanaan pembelajaran disajikan dalam waktu 2 x 50 menit.

Materi yang diambil adalah adaptasi dan evolusi. Adapun kompetensi dasar pada materi adaptasi dan evolusi yaitu mendeskripsikan adaptasi dan evolusi. Indikator yang akan dicapai dalam pembelajaran adaptasi dan evolusi pada siklus I adalah : 1) Mahasiswa dapat menjelaskan pengertian adaptasi dan evolusi, 2) Mahasiswa dapat menjelaskan beragam adaptasi, 3) Mahasiswa dapat menjelaskan factor-faktor munculnya adaptasi dan evolusi, 4) Mahasiswa dapat menjelaskan teori-teori pendukung adaptasi dan evolusi, 5) Mahasiswa dapat menjelaskan hubungan reproduksi manusia, adaptasi dan evolusi, 6) Mahasiswa dapat memberikan contoh-contoh adaptasi dan evolusi dalam fenomena nyata di alam. Untuk mencapai indikator yang telah ditentukan, maka peneliti menggunakan strategi Problem based learning dalam pembelajaran dengan mengikuti langkahlangkah pembelajaran yang telah ditentukan.

Pelaksanaan pembelajaran dilakukan dengan tiga tahap yaitu kegiatan awal, kegiatan inti dan kegiatan akhir. Pelaksanaannya berdasarkan langkahlangkah dari Problem based learning menurut Trianto dalam Taufik (2009 : 372373) yaitu (1) Orientasi peserta didik pada masalah; (2) mengorganisasikan peserta didik untuk belajar; (3) membimbing penyelidikan individual maupun kelompok; (4) mengembangkan dan menyajikan hasil karya; (5) menganalisis dan mengevaluasi proses pemecahan masalah.

\section{1) Hasil Penilaian Rencana Pelaksanaan Pembelajaran (RPP)}

Pada dalam siklus I instrumen penilaian RPP dilakukan oleh observer. Dari hasil penilaian RPP diperoleh persentase 70,83 $\%$ dengan kualifikasi cukup (C).

2) Pengamatan dalam Pelaksanaan Pembelajaran IPA dengan menggunakan model PBL

\section{a) Pengamatan Aspek Dosen}

Hasil pengamatan yang dilakukan observer terhadap aktivitas dosen selaku peneliti dalam kegiatan pembelajaran pada siklus I dalam pembelajaran IPA menggunakan model PBL adalah memperoleh tingkat keberhasilan $75 \%$ dengan kategori cukup. 


\section{(b) Pengamatan Aktivitas Mahasiswa}

Berdasarkan hasil pengamatan yang dilakukan oleh pengamat terhadap aktivitas mahasiswa dalam kegiatan pembelajaran siklus I, persentase rata-rata aktivitas mahasiswa adalah 67,86\% dengan kategori cukup.

\section{(c) Pengamatan Kreativitas Mahasiswa}

Dari hasil pengamatan terhadap pembelajaran pada siklus I, diperoleh bahwa materi pembelajaran tersebut bagi mahasiswa masih banyak yang belum jelas. Hanya 22\% mahasiswa (6 orang mahasiswa dari 27 mahasiswa) yang berpikir kreatif karena mahasiswa memiliki banyak keraguraguan dan pola pikirnya masih mengacu pada materi umum. Dari 6 orang tersebut, secara umum memiliki kriteria cukup dengan persentase $70 \%$.

\section{1) Refleksi RPP}

Berdasarkan dari hasil pengamatan yang dilaksanakan, maka untuk selanjutnya dosen perlu memperhatikan hal-hal sebagai berikut: (1) pemilihan materi ajar lebih disesuai dengan karakteristik mahasiswa, (2) materi ajar lebih disesuai dengan lingkungan yang tersedia, (3) pengorganisasian materi yang diajarkan dosen menyesuaikan alokasi waktu yang ditentukan, (4) pemilihan sumber dan media pembelajaran lebih dekat dan sesuai dengan karakteristik mahasiswa, (5) pemilihan sumber dan media pembelajaran lebih dekat dan sesuai dengan lingkungan mahasiswa, (6) langkah pembelajaran sesuai dengan alokasi waktu, (7) teknik pembelajaran sesuai dengan lingkungan mahasiswa.

\section{2) Refleksi Pelaksanaan Pembelajaran IPA dengan Menerapkan Model PBL}

\section{(a) Refleksi Aspek Dosen}

Berdasarkan dari hasil pengamatan, maka untuk selanjutnya dosen perlu memperhatikan hal-hal berikut: (1) dalam orientasi mahasiswa kepada masalah, dosen meminta mahasiswa untuk mengungkapkan masalah tentang objek yang pernah diamati sebelumnya terkait permasalahan tersebut.
(2) Dalam mengorganisasikan mahasiswa untuk belajar, dosen meminta mahasiswa untuk saling membagi tugas pada masingmasing kelompok. (3) Dalam membimbing penyelidikan individual maupun kelompok, dosen menyediakan alat dan bahan pembelajaran sehingga mahasiswa bisa memperoleh informasi dari berbagai sumber lainnya.

(4) Dalam mengembangkan dan menyajikan hasil karya, dosen meminta semua kelompok tampil untuk mempresentasikan laporannya dan memotivasi mahasiswa untuk bertanya atau memberikan saran, (5) Dalam menganalisis dan mengevaluasi proses pemecahan masalah, dosen meminta mahasiswa lain untuk menilai hasil presentasi laporan dari kelompok penyaji dan meminta kelompok penyaji untuk menjawab semua pertanyaan mahasiswa lain.

\section{3) Refleksi Aspek Mahasiswa}

Berdasarkan hasil pengamatan, maka untuk selanjutnya dosen perlu memperhatikan: (1) Dalam mengkondisikan kelas dan apppersepsi, dosen mengarahkan mahasiswa untuk bersikap tenang. (2) Dalam orientasi mahasiswa kepada masalah, dosen memotivasi mahasiswa untuk menjawab pertanyaan yang diberikan dosen tentang adaptasi dan evolusi, dan mahasiswa mengungkapkan masalah tentang objek yang pernah diamati sebelumnya terkait permasalahan tersebut. (3) Dalam mengorganisasikan mahasiswa untuk belajar, dosen perlu mengarahkan tugas yang akan dikerjakan mahasiswa dan peranan masing-masing anggota kelompok dalam mengerjakan tugas tersebut.

(4) Dalam membimbing penyelidikan individual maupun kelompok, dosen perlu menyiapkan alat dan bahan untuk pembelajaran sehingga mahasiswa dapat memperoleh informasi dari sumber lainnya, dan dosen perlu memotivasi mahasiswa dalam menyampaikan ide dan pendapatnya dalam melakukan diskusi kelompok. (5) Dalam mengembangkan dan menyajikan 
hasil karya, dosen perlu mengefektifkan waktu agar mahasiswa tampil dapat tampil untuk mempresentasikan laporannya dalam waktu yang singkat, dan memancing mahasiswa lain untuk bertanya atau memberikan saran. (6) Dalam menganalisis dan mengevaluasi proses pemecahan masalah, dosen perlu mengarahkan mahasiswa untuk menilai hasil presentasi laporan dari kelompok penyaji dan mengarahkan kelompok penyaji untuk menjawab pertanyaan dari mahasiswa lain. (7) Dalam menyimpulkan, dosen lebih mengarahkan mahasiswa untuk menyimpulkan hasil diskusi kelompok.

\section{4) Refleksi Kreativitas Mahasiswa}

Berdasarkan hasil penilaian kreativitas mahasiswa, maka dapat dilihat deskriptor yang belum tercapai dalam kreativitas yang diuraikan sebagai berikut: Pada siklus I di tingkat I (fungsi divergen) belum tercapai karena pendapat mahasiswa belum orisinil; elaborasi belum tercapai dan kemampuan menilai belum sempurna. Untuk selanjutnnya perlu memaksimalkan kegiatan dalam membimbing penyelidikan individual maupun kelompok, mengembangkan dan menyajikan hasil karya serta menganalisis dan mengevaluasi proses pemecahan masalah.

Indikator yang belum tercapai pada tingkat II (proses berpikir) karena mahasiswa belum menganalisis proses berfikir; melakukan sintesis proses berfikir hasil analisa cepat dan tepat; keterampilan metodologis untuk memecahkan masalah; transformasi proses berfikir dapat memenuhi kriteria pemecahan masalah; dan metafor dan analogi terhadap proses berfikir sehingga dapat mengubah gagasan dan mengemukakan ide-ide baru. Untuk itu perlu dilakukan memaksimalkan langkah pembelajaran yaitu mengembangkan dan menyajikan hasil karya; serta menganalisis dan mengevaluasi proses pemecahan masalah.

Pada tingkat III (keterlibatan dalam fenomena nyata) belum tercapai karena mahasiswa belum maksimal dalam pengajuan pertanyaan secara mandiri; pengarahan diri terhadap tantangantantangan nyata dalam kehidupan; pengelolaan dan sumber informasi, tenaga dan biaya; dan pengembangan produk dan hasil gagasan atau ide-ide kreatif. Untuk selanjutnya perlu memaksimalkan langkah pembelajaran yaitu: membimbing penyelidikan individu maupun kelompok, mengembangkan dan menyajikan hasil karya; serta menganalisis dan mengevaluasi proses pemecahan masalah. Dan dengan pertanyaan yang mengarahkan mahasiswa dalam menemukan jawabannya.

\section{Siklus II Pertemuan 1}

Pada tahap perencanaan, peneliti mempersiapkan perangkat pembelajaran IPA berupa RPP dengan penerapan model problem based learning. Adapun komponen penyusunannya dirancang berdasarkan analisis SK dan KD yang dikembangkan menjadi indikator dan kemudian tujuan pembelajaran. Perencanaan pembelajaran disajikan dalam waktu 2 x 50 menit.

Materi yang diambil pada materi siklus II adalah reproduksi manusia. Hal ini dikarenakan indikator pembelajaran pada siklus I belum tercapai. Adapun kompetensi dasar pada materi reproduksi manusia yaitu mendeskripsikan reproduksi pada manusia. Indikator yang akan dicapai dalam pembelajaran reproduksi manusia pada siklus II adalah : 2) Mahasiswa dapat menjelaskan proses terbentuknya individu baru, 3) Mahasiswa dapat menjelaskan faktor-faktor pendorong dan penghambat terbentuknya individu baru. Untuk mencapai indikator yang telah ditentukan maka peneliti menggunakan strategi Problem Based Learning dalam pembelajaran dengan mengikuti langkahlangkah pembelajaran yang telah ditentukan.

Pelaksanaan pembelajaran dilakukan dengan tiga tahap yaitu kegiatan awal, kegiatan inti dan kegiatan akhir. Pelaksanaannya berdasarkan langkah- 
langkah dari Problem Based Learning menurut Trianto dalam Taufik (2009 : 372373) yaitu (1) Orientasi peserta didik pada masalah; (2) mengorganisasikan peserta didik untuk belajar; (3) membimbing penyelidikan individual maupun kelompok; (4) mengembangkan dan menyajikan hasil karya; (5) menganalisis dan mengevaluasi proses pemecahan masalah.

1) Hasil Penilaian Rencana Pelaksanaan Pembelajaran (RPP)

Pada dalam siklus II instrumen penilaian RPP dilakukan oleh observer. Dari hasil penilaian RPP diperoleh persentase 83,33\% dengan kualifikasi baik (B).

2) Pengamatan dalam Pelaksanaan Pembelajaran IPA dengan menggunakan model PBL

\section{a) Pengamatan Aspek Dosen}

Hasil pengamatan yang dilakukan observer terhadap aktivitas dosen selaku peneliti dalam kegiatan pembelajaran pada siklus II dalam pembelajaran IPA menggunakan model PBL adalah memperoleh tingkat keberhasilan 89,29\% dengan kategori sangat baik.

\section{(b) Pengamatan Aktivitas Mahasiswa}

Berdasarkan hasil pengamatan yang dilakukan oleh pengamat terhadap aktivitas mahasiswa dalam kegiatan pembelajaran siklus II, persentase rata-rata aktivitas mahasiswa adalah 82,14\% dengan kategori baik.

\section{(c) Pengamatan Kreativitas Mahasiswa}

Dari hasil pengamatan terhadap pembelajaran pada siklus II, diperoleh bahwa materi pembelajaran tersebut bagi mahasiswa baru mulai tergambar. Mahasiswa yang berpikir kreatif meningkat dari 11 orang menjadi 16 orang berkisar $59 \%$ mahasiswa (16 orang mahasiswa dari 27 mahasiswa) sehingga pola pikir yang terbentuk dalam proses dan baru memiliki gambaran tentang materi tersebut. Dari 16 orang, secara umum memiliki kriteria baik dengan persentase $81 \%$.

\section{1) Refleksi RPP}

Berdasarkan dari hasil pengamatan yang dilaksanakan, maka untuk selanjutnya dosen perlu memperhatikan hal-hal sebagai berikut: (1) materi ajar lebih disesuai kembali dengan bahan yang akan diajarkan, (2) pengorganisasian materi yang diajarkan dosen menyesuaikan alokasi waktu yang ditentukan, pemilihan sumber dan media pembelajaran lebih dekat dan sesuai dengan lingkungan mahasiswa, (4) langkah pembelajaran sesuai dengan alokasi waktu.

\section{2) Refleksi Pelaksanaan Pembelajaran IPA dengan Menerapkan Model PBL}

\section{(a) Refleksi Aspek Dosen}

Berdasarkan dari hasil pengamatan, maka untuk selanjutnya dosen perlu memperhatikan hal-hal berikut: (1) Dalam membimbing penyelidikan individual maupun kelompok, dosen mendekatkan mahasiswa pada masyarakat sehingga mahasiswa bisa memperoleh informasi dari berbagai sumber lainnya. (2) Dalam mengembangkan dan menyajikan hasil karya, dosen meminta semua kelompok tampil untuk menyerahkan laporannya, (3) Dalam menganalisis dan mengevaluasi proses pemecahan masalah, dosen memotivasi dan mengarahkan kelompok penyaji untuk menjawab semua pertanyaan mahasiswa lain.

\section{3) Refleksi Aspek Mahasiswa}

Berdasarkan hasil pengamatan, maka untuk selanjutnya dosen perlu memperhatikan: (1) Dalam orientasi mahasiswa kepada masalah, dosen memotivasi mahasiswa untuk mencatat informasi yang diperoleh dari berbagai sumber. (2) Dalam membimbing penyelidikan individual maupun kelompok, dosen mencari sumber pembelajaran lain sehingga mahasiswa dapat memperoleh informasi dari sumber. (3) Dalam mengembangkan dan menyajikan hasil karya, dosen mengarahkan mahasiswa untuk membuat laporan dan menyerahkannya kepada dosen di akhir perkuliahan. (4) Dalam 
menganalisis dan mengevaluasi proses pemecahan masalah, dosen perlu memotivasi mahasiswa lainnya untuk terlibat dalam penilaian hasil presentasi laporan dari kelompok penyaji dan meminta kelompok penyaji untuk menyempurnakan jawabanya.

\section{4) Refleksi Kreativitas Mahasiswa}

Berdasarkan hasil penilaian kreativitas mahasiswa, maka dapat dilihat deskriptor yang belum tercapai dalam kreativitas yang diuraikan sebagai berikut: Masih ada indikator yang belum tercapai pada tingkat II (proses berpikir) dikarenakan mahasiswa belum maksimal dalam melakukan sintesis proses berfikir hasil analisa cepat dan tepat. Untuk itu perlu dilakukan adalah memaksimalkan langkah pembelajaran yaitu mengevaluasi proses pemecahan masalah.

Pada tingkat III (keterlibatan dalam fenomena nyata) belum tercapai karena mahasiswa belum maksimal dalam pengajuan pertanyaan secara mandiri; pengarahan diri terhadap tantangantantangan nyata dalam kehidupan; pengelolaan dan sumber informasi, tenaga dan biaya; dan pengembangan produk dan hasil gagasan atau ide-ide kreatif. Untuk selanjutnya perlu memaksimalkan langkah pembelajaran yaitu: membimbing penyelidikan individu maupun kelompok, mengembangkan dan menyajikan hasil karya; serta menganalisis dan mengevaluasi proses pemecahan masalah.

\section{4. $\quad$ Siklus II Pertemuan 2}

Pada tahap perencanaan, peneliti mempersiapkan perangkat pembelajaran IPA berupa RPP dengan penerapan model problem based learning. Adapun komponen penyusunannya dirancang berdasarkan analisis SK dan KD yang dikembangkan menjadi indikator dan kemudian tujuan pembelajaran. Perencanaan pembelajaran disajikan dalam waktu 2 x 50 menit.

Materi yang diambil pada materi siklus II adalah adaptasi dan evolusi. Hal ini dikarenakan indikator pembelajaran pada siklus I belum tercapai. Adapun kompetensi dasar pada materi adaptasi dan evolusi yaitu mendeskripsikan adaptasi dan evolusi. Indikator yang akan dicapai dalam pembelajaran adaptasi dan evolusi pada siklus II adalah : 3) Mahasiswa dapat menjelaskan faktor-faktor munculnya adaptasi dan evolusi, 5) Mahasiswa dapat menjelaskan hubungan reproduksi manusia, adaptasi dan evolusi, 6) Mahasiswa dapat memberikan contoh adaptasi dan evolusi dalam fenomena nyata di alam. Untuk mencapai indikator yang telah ditentukan maka peneliti menggunakan strategi Problem based learning dalam pembelajaran dengan mengikuti langkahlangkah pembelajaran yang telah ditentukan.

Pelaksanaan pembelajaran dilakukan dengan tiga tahap yaitu kegiatan awal, kegiatan inti dan kegiatan akhir. Pelaksanaannya berdasarkan langkahlangkah dari Problem based learning menurut Trianto dalam Taufik (2009 : 372373) yaitu (1) Orientasi peserta didik pada masalah; (2) mengorganisasikan peserta didik untuk belajar; (3) membimbing penyelidikan individual maupun kelompok; (4) mengembangkan dan menyajikan hasil karya; (5) menganalisis dan mengevaluasi proses pemecahan masalah.

\section{1) Hasil Penilaian Rencana Pelaksanaan Pembelajaran (RPP)}

Pada dalam siklus II instrumen penilaian RPP dilakukan oleh observer. Dari hasil penilaian RPP diperoleh persentase $79,17 \%$ dengan kualifikasi baik (B).

\section{2) Pengamatan dalam Pelaksanaan Pembelajaran IPA dengan menggunakan model PBL}

\section{a) Pengamatan Aspek Dosen}

Hasil pengamatan yang dilakukan observer terhadap aktivitas dosen selaku peneliti dalam kegiatan pembelajaran pada siklus II dalam pembelajaran IPA menggunakan model PBL adalah memperoleh tingkat keberhasilan $89,29 \%$ dengan kategori sangat baik. 
(b) Pengamatan Aktivitas Mahasiswa

Berdasarkan hasil pengamatan yang dilakukan oleh pengamat terhadap aktivitas mahasiswa dalam kegiatan pembelajaran siklus II, persentase rata-rata aktivitas mahasiswa adalah 78,57 \% dengan kategori baik.

\section{(c) Pengamatan Kreativitas Mahasiswa}

Dari hasil pengamatan terhadap pembelajaran pada siklus II, diperoleh bahwa materi pembelajaran tersebut bagi mahasiswa baru mulai tergambar. Mahasiswa yang berpikir kreatif meningkat dari 6 orang menjadi 18 orang berkisar $67 \%$ mahasiswa (18 orang mahasiswa dari 27 mahasiswa) sehingga pola pikir yang terbentuk dalam proses dan baru memiliki gambaran tentang materi tersebut. Dari 18 orang, secara umum memiliki kriteria cukup dengan persentase $76 \%$.

\section{1) Refleksi RPP}

Berdasarkan dari hasil pengamatan yang dilaksanakan, maka untuk selanjutnya dosen perlu memperhatikan hal-hal sebagai berikut: (1) materi ajar lebih disesuai kembali dengan lingkungan yang tersedia, (2) pengorganisasian materi yang diajarkan dosen menyesuaikan alokasi waktu yang ditentukan, (3) pemilihan sumber dan media pembelajaran lebih dekat dan sesuai dengan lingkungan mahasiswa, (4) langkah pembelajaran sesuai dengan alokasi waktu.

\section{2) Refleksi Pelaksanaan Pembelajaran} IPA dengan Menerapkan Model PBL

\section{(a) Refleksi Aspek Dosen}

Berdasarkan dari hasil pengamatan, maka untuk selanjutnya dosen perlu memperhatikan hal-hal berikut: (1) Dalam membimbing penyelidikan individual maupun kelompok, dosen mendekatkan mahasiswa pada alam sehingga mahasiswa bisa memperoleh informasi dari berbagai sumber lainnya. (2) Dalam mengembangkan dan menyajikan hasil karya, dosen meminta semua kelompok tampil untuk menyerahkan laporannya, (3) Dalam menganalisis dan mengevaluasi proses pemecahan masalah, dosen memotivasi dan mengarahkan mahasiswa untuk menilai hasil presentasi laporan dari kelompok penyaji.

\section{3) Refleksi Aspek Mahasiswa}

Berdasarkan hasil pengamatan, maka untuk selanjutnya dosen perlu memperhatikan: (1) Dalam orientasi mahasiswa kepada masalah, dosen memotivasi mahasiswa untuk mencatat informasi yang diperoleh. (2) Dalam membimbing penyelidikan individual maupun kelompok, dosen mencari sumber pembelajaran lain sehingga mahasiswa dapat memperoleh informasi dari sumber lainnya untuk memecahkan masalah. (3) Dalam mengembangkan dan menyajikan hasil karya, dosen mengarahkan mahasiswa untuk membuat laporan dan menyerahkannya kepada dosen di akhir perkuliahan. (4) Dalam menganalisis dan mengevaluasi proses pemecahan masalah, dosen perlu memotivasi mahasiswa lainnya untuk terlibat dalam penilaian hasil presentasi laporan dari kelompok penyaji dan meminta kelompok penyaji untuk menyempurnakan jawabanya.

\section{4) Refleksi Kreativitas Mahasiswa}

Berdasarkan hasil penilaian kreativitas mahasiswa, maka dapat dilihat deskriptor yang belum tercapai dalam kreativitas yang diuraikan sebagai berikut:

(1) Indikator pada tingkat I (fungsi divergen) belum tercapai karena mahasiswa berpendapat belum orisinilitas; belum adanya elaborasi dan belum maksimalnya kemampuan menilai. Untuk selanjutnya, perlu peningkatan dalam kegiatan membimbing penyelidikan individual maupun kelompok; mengembangkan dan menyajikan hasil karya; dan menganalisis dan mengevaluasi proses pemecahan masalah.

(2) Indikator pada tingkat II (proses berpikir) belum tercapai karena belum maksimal dalam sintesis proses berfikir hasil analisa cepat dan tepat; evaluasi terhadap proses berfikir terhadap masalah 
yang ditemukan; dan transformasi proses berfikir dapat memenuhi kriteria pemecahan masalah. Untuk selanjutnya perlu dilakukan peningkatan dalam kegiatan mengembangkan dan menyajikan hasil karya; dan menganalisis dan mengevaluasi proses pemecahan masalah.

(3) Indikator pada tingkat III (keterlibatan dalam fenomena nyata) belum tercapai karena pengarahan diri terhadap tantangan-tantangan nyata dalam kehidupan; pengelolaan dan sumber informasi, tenaga dan biaya; dan pengembangan produk dan hasil gagasan atau ide-ide kreatif belum maksimal dilakukan. Untuk selanjutnya perlu dilakukan peningkatan dalam kegiatan mengembangkan dan menyajikan hasil karya; dan menganalisis dan mengevaluasi proses pemecahan masalah

\section{Siklus III Pertemuan 1}

Pada tahap perencanaan, peneliti mempersiapkan perangkat pembelajaran IPA berupa RPP dengan penerapan model problem based learning. Adapun komponen penyusunannya dirancang berdasarkan analisis SK dan KD yang dikembangkan menjadi indikator dan kemudian tujuan pembelajaran. Perencanaan pembelajaran disajikan dalam waktu 2 x 50 menit.

Materi yang diambil pada materi siklus III adalah reproduksi manusia. Hal ini dikarenakan indikator pembelajaran pada siklus II masih belum tercapai. Adapun kompetensi dasar pada materi reproduksi manusia yaitu mendeskripsikan reproduksi pada manusia. Indikator yang akan dicapai dalam pembelajaran reproduksi manusia pada siklus III adalah : Mahasiswa dapat menjelaskan faktor-faktor pendorong dan penghambat terbentuknya individu baru. Untuk mencapai indikator yang telah ditentukan maka peneliti menggunakan strategi Problem Based Learning dalam pembelajaran dengan mengikuti langkahlangkah pembelajaran yang telah ditentukan.
Pelaksanaan pembelajaran dilakukan dengan tiga tahap yaitu kegiatan awal, kegiatan inti dan kegiatan akhir. Pelaksanaannya berdasarkan langkahlangkah dari Problem Based Learning menurut Trianto dalam Taufik (2009 : 372373) yaitu (1) Orientasi peserta didik pada masalah; (2) mengorganisasikan peserta didik untuk belajar; (3) membimbing penyelidikan individual maupun kelompok; (4) mengembangkan dan menyajikan hasil karya; (5) menganalisis dan mengevaluasi proses pemecahan masalah.

1) Hasil Penilaian Rencana Pelaksanaan Pembelajaran (RPP)

Pada siklus III instrumen penilaian RPP dilakukan oleh observer. Dari hasil penilaian RPP diperoleh persentase 95,83 $\%$ dengan kualifikasi sangat baik (SB).

2) Pengamatan dalam Pelaksanaan Pembelajaran IPA dengan menggunakan model PBL

a) Pengamatan Aspek Dosen

Hasil pengamatan yang dilakukan observer terhadap aktivitas dosen selaku peneliti dalam kegiatan pembelajaran pada siklus III dalam pembelajaran IPA menggunakan model PBL adalah memperoleh tingkat keberhasilan 96,43\% dengan kategori sangat baik.

\section{(b) Pengamatan Aktivitas Mahasiswa}

Berdasarkan hasil pengamatan yang dilakukan oleh pengamat terhadap aktivitas mahasiswa dalam kegiatan pembelajaran siklus III, persentase rata-rata aktivitas mahasiswa adalah 92,86 \% dengan kategori sangat baik.

\section{(c) Pengamatan Kreativitas Mahasiswa}

Dari hasil pengamatan terhadap pembelajaran pada siklus III, diperoleh bahwa materi pembelajaran tersebut bagi mahasiswa sudah jelas. Mahasiswa yang berpikir kreatif meningkat dari 16 orang menjadi 27 orang $(100 \%)$ sehingga pola pikir yang terbentuk telah tergambar jelas karena terjun ke masyarakat. Dari 27 orang, secara umum memiliki kriteria sangat baik dengan persentase $92 \%$. 


\section{Siklus III Pertemuan 2}

Hasil penelitian pada siklus III meliputi pada perencanaan pembelajaran, pelaksanaan pembelajaran dengan materi adaptasi dan evolusi dengan menerapkan model PBL. Pengamatan selama proses pembelajaran meliputi hasil penilaian RPP, hasil pengamatan aspek dosen dan mahasiswa, serta kreativitas mahasiswa. Kemudian dari hal yang dilakukan inilah yang kemudian dilakukan refleksi

\section{a. Perencanaan Pembelajaran Siklus} III Pertemuan 2

Pada tahap perencanaan, peneliti mempersiapkan perangkat pembelajaran IPA berupa RPP dengan penerapan model problem based learning. Adapun komponen penyusunannya dirancang berdasarkan analisis SK dan KD yang dikembangkan menjadi indikator dan kemudian tujuan pembelajaran. Perencanaan pembelajaran disajikan dalam waktu $2 \times 50$ menit.

Materi yang diambil pada materi siklus III adalah adaptasi dan evolusi. Hal ini dikarenakan indikator pembelajaran pada siklus II masih belum tercapai. Adapun kompetensi dasar pada materi adaptasi dan evolusi yaitu mendeskripsikan adaptasi dan evolusi. Indikator yang akan dicapai dalam pembelajaran adaptasi dan evolusi pada siklus III adalah : 3) Mahasiswa dapat menjelaskan faktor-faktor munculnya adaptasi dan evolusi, dan 6) mahasiswa dapat memberikan contoh adaptasi dan evolusi dalam fenomena nyata di alam. Untuk mencapai indikator yang telah ditentukan maka peneliti menggunakan strategi Problem based learning dalam pembelajaran dengan mengikuti langkahlangkah pembelajaran yang telah ditentukan.

Pelaksanaan pembelajaran dilakukan dengan tiga tahap yaitu kegiatan awal, kegiatan inti dan kegiatan akhir. Pelaksanaannya berdasarkan langkahlangkah dari Problem based learning menurut Trianto dalam Taufik (2009 : 372373) yaitu (1) Orientasi peserta didik pada masalah; (2) mengorganisasikan peserta didik untuk belajar; (3) membimbing penyelidikan individual maupun kelompok; (4) mengembangkan dan menyajikan hasil karya; (5) menganalisis dan mengevaluasi proses pemecahan masalah.

\section{1) Hasil Penilaian Rencana Pelaksanaan Pembelajaran (RPP)}

Pada siklus III instrumen penilaian RPP dilakukan oleh observer. Dari hasil penilaian RPP diperoleh persentase 95,83 $\%$ dengan kualifikasi sangat baik (SB).

\section{2) Pengamatan dalam Pelaksanaan Pembelajaran IPA dengan menggunakan model PBL}

\section{a) Pengamatan Aspek Dosen}

Hasil pengamatan yang dilakukan observer terhadap aktivitas dosen selaku peneliti dalam kegiatan pembelajaran pada siklus III dalam pembelajaran IPA menggunakan model PBL adalah memperoleh tingkat keberhasilan 96,43\% dengan kategori sangat baik.

\section{(b) Pengamatan Aktivitas Mahasiswa}

Berdasarkan hasil pengamatan yang dilakukan oleh pengamat terhadap aktivitas mahasiswa dalam kegiatan pembelajaran siklus III, persentase rata-rata aktivitas mahasiswa adalah 96,43 \% dengan kategori sangat baik.

\section{(c) Pengamatan Kreativitas Mahasiswa}

Dari hasil pengamatan terhadap pembelajaran pada siklus III, diperoleh bahwa materi pembelajaran tersebut bagi mahasiswa sudah jelas. Mahasiswa yang berpikir kreatif meningkat dari 18 orang menjadi 27 orang $(100 \%)$ sehingga pola pikir yang terbentuk telah tergambar jelas karena melihat fenomena yang terjadi di alam. Dari 27 orang, secara umum memiliki kriteria baik dengan persentase $89 \%$.

\section{PENUTUP}

Pada siklus I masih banyak deskriptor yang belum muncul sehingga pengamatan RPP pada siklus I memperoleh nilai persentase rata-rata $68,75 \%$ dengan kategori cukup. Selanjutnya pada siklus II, dosen sudah 
perbaikan pada RPP sehingga nilai presentase pada siklus II menjadi $83,33 \%$ dengan kualifikasi baik. Dalam hal ini masih terdapat deskriptor yang belum muncul, kemudian dilanjutkan pada siklus III. Pada siklus III, dosen melakukan perbaikan kembali pada RPP sehingga persentae pada siklus III menjadi 95,83\% dengan kategori sangat baik. Dari siklus I ke siklus II terjadi peningkatan 14,58\%, sedangkan siklus II ke siklus III terjadi peningkatan $12,5 \%$

Berdasarkan hasil pengamatan pelaksanaan dari aktivitas dosen maupun mahasiswa pada siklus I, II dan III, terlihat bahwa peningkatan yang terjadi sangat dipengaruhi oleh interaksi dan komunikasi yang baik melalui motivasi dosen kepada mahasiswa dalam mengikuti pembelajaran IPA dengan penerapan model PBL. Berdasarkan hasil pengamatan aktivitas dosen pada siklus I memperoleh persentase $73,22 \%$ dengan kualifikasi cukup. Selanjutnya pada siklus II memperoleh nilai persentase 89,29\% dengan kualifikasi sangat baik. Kemudian pada siklus III memperoleh nilai persentase $96,43 \%$ engan kualifikasi sangat baik. Pelaksanaan pembelajaran model PBL dari aspek dosen mengalami peningkatan dari siklus I ke siklus II sebesar 16,08\% dan dari siklus II ke siklus III sebesar 7,14\%.

Hasil pengamatan pelaksanaan dari aspek mahasiswa pada siklus I memperoleh nilai persentase $62,5 \%$ dengan kualifikasi cukup. Selanjutnya pada siklus II memperoleh nilai persentase $82,14 \%$ dengan kualifikasi baik. Pada siklus III memperoleh nilai persentase 94,65\% dengan kualifikasi sangat baik. Pelaksanaan pembelajaran model PBL dari aspek mahasiswa mengalami peningkatan dari siklus I ke siklus II sebesar 19,64\% dan dari siklus II ke siklus III sebesar 12,51\%.

Kreativitas mahasiswa dalam pembelajaran IPA dengan materi reproduksi manusia dengan penerapan model PBL menunjukkan peningkatan kreativitas mahasiswa selama proses pembelajaran berlangsung. Hal ini dapat terlihat dari mahasiswa yang aktif terlibat dalam proses pembelajaran berlangsung dengan mengemukakan ide-ide melalui tanya jawab. Adapun hasilnya adalah $41 \%$ mahasiswa (11 orang mahasiswa dari 27 mahasiswa) yang berpikir kreatif karena materi pembelajaran masih bersifat abstrak, sehingga pola pikir yang terbentuk dalam proses dan memiliki banyak keragu-raguan. Dari 11 orang tersebut, secara umum memiliki kriteria kurang dengan persentase $61 \%$. Untuk siklus I di tingkat I (fungsi divergen) diperoleh rata-rata $70 \%$ dengan kategori cukup. Pada tingkat II (proses berpikir) siklus I memiliki persentase $63 \%$ dengan kriteria kurang. Sedangkan pada tingkat III (keterlibatan dalam fenomena nyata) secara umum memiliki persentase 46\% dengan kriteria sangat kurang.

Pada siklus II hasilnya adalah mahasiswa yang berpikir kreatif meningkat dari 11 orang menjadi 16 orang berkisar 59\% mahasiswa (16 orang mahasiswa dari 27 mahasiswa) sehingga pola pikir yang terbentuk dalam proses dan baru memiliki gambaran tentang materi tersebut. Dari 16 orang, secara umum memiliki kriteria baik dengan persentase $81 \%$. Untuk siklus II di tingkat I (fungsi divergen) diperoleh ratarata $89 \%$ dengan kategori baik. Pada tingkat II (proses berpikir) siklus II memiliki persentase $87 \%$ dengan kriteria baik. Sedangkan pada tingkat III (keterlibatan dalam fenomena nyata) secara umum memiliki persentase $59 \%$ dengan kriteria sangat kurang.

Pada siklus III hasilnya adalah mahasiswa yang berpikir kreatif meningkat dari 16 orang menjadi 27 orang $(100 \%)$ sehingga pola pikir yang terbentuk telah tergambar jelas karena terjun ke masyarakat. Dari 27 orang, secara umum memiliki kriteria sangat baik dengan persentase 92\%. Untuk siklus III di tingkat I (fungsi divergen) diperoleh rata-rata 96\% dengan kategori sangat baik. Pada tingkat II (proses berpikir) siklus III memiliki persentase $90 \%$ dengan kriteria sangat baik. Sedangkan 
pada tingkat III (keterlibatan dalam fenomena nyata) secara umum memiliki persentase 94\% dengan kriteria sangat baik. Dengan demikian, terjadi peningkatan kreativitas mahasiswa pada pembelajaran IPA dengan menerapkan model PBL.

Kreativitas mahasiswa dalam pembelajaran IPA dengan materi adaptasi dan evolusi dengan penerapan model PBL menunjukkan peningkatan kreativitas mahasiswa selama proses pembelajaran berlangsung. Hal ini dapat terlihat dari mahasiswa yang aktif terlibat dalam proses pembelajaran berlangsung dengan mengemukakan ide-ide melalui tanya jawab. Adapun hasilnya adalah 22\% mahasiswa (6 orang mahasiswa dari 27 mahasiswa) yang berpikir kreatif karena materi pembelajaran masih bersifat abstrak, sehingga pola pikir yang terbentuk dalam proses dan memiliki banyak keraguraguan.Dari 6 orang tersebut, secara umum memiliki kriteria cukup dengan persentase $70 \%$. Untuk siklus I di tingkat I (fungsi divergen) diperoleh rata-rata $81 \%$ dengan kategori baik. Pada tingkat II (proses berpikir) siklus I memiliki persentase $71 \%$ dengan kriteria cukup. Sedangkan pada tingkat III (keterlibatan dalam fenomena nyata) secara umum memiliki persentase $56 \%$ dengan kriteria sangat kurang.

Pada siklus II hasilnya adalah mahasiswa yang berpikir kreatif meningkat dari 6 orang menjadi 18 orang berkisar $67 \%$ mahasiswa (18 orang mahasiswa dari 27 mahasiswa) sehingga pola pikir yang terbentuk dalam proses dan baru memiliki gambaran tentang materi tersebut. Dari 18 orang, secara umum memiliki kriteria cukup dengan persentase $76 \%$. Untuk siklus II di tingkat I (fungsi divergen) diperoleh rata-rata $79 \%$ dengan kategori cukup. Pada tingkat II (proses berpikir) siklus II memiliki persentase $77 \%$ dengan kriteria cukup. Sedangkan pada tingkat III (keterlibatan dalam fenomena nyata) secara umum memiliki persentase $71 \%$ dengan kriteria cukup.

Pada siklus III hasilnya adalah mahasiswa yang berpikir kreatif meningkat dari 18 orang menjadi 27 orang (100\%) sehingga pola pikir yang terbentuk telah tergambar jelas karena terjun ke masyarakat. Dari 27 orang, secara umum memiliki kriteria baik dengan persentase $89 \%$. Untuk siklus III di tingkat I (fungsi divergen) diperoleh ratarata $88 \%$ dengan kategori baik. Pada tingkat II (proses berpikir) siklus III memiliki persentase $87 \%$ dengan kriteria baik. Sedangkan pada tingkat III (keterlibatan dalam fenomena nyata) secara umum memiliki persentase 93\% dengan kriteria sangat baik. Dengan demikian, terjadi peningkatan kreativitas mahasiswa pada pembelajaran IPA dengan menerapkan model PBL.

\section{DAFTAR PUSTAKA}

Amir, M. Taufiq. 2010. Inovasi Pendidikan Melalui Problem based learning : Bagaimana Pendidik Memberdayakan Pemelajaran di Era Pengetahuan. Jakarta : Kencana Prenada Media Grup.

Munandar, Utami. 1999. Kreativitas dan Keberbakatan. Jakarta : Gramedia

Munandar, Utami. 2004. Pengembangan Kreativitas Anak Berbakat. Jakarta : Rineka Cipta.

Rusman. Model-model Pembelajaran : Mengembangkan Profesionalisme Guru. Jakarta : Grafindo Persada.

Suharsimi, Arikunto, Suhardjono dan Supardi. 2008. Penelitian Tindakan Kelas. Jakarta : Bumi Aksara.

Taufik, Taufina dan Muhammadi. 2009. Mozaik Pembelajaran Inovatif. Padang : Sukabina Press 